Spritled Silaye

\title{
Cantar and Efferta
}

B 195
P3
opy 1

\begin{abstract}
Het
\end{abstract}







\title{
Spoiled Silage
}

Sour Silage

Moldy Silage

Rotten Silage

Frozen Silage

\section{Its}

\section{Cause and Effects}

(The sure cure is the preventive)

\author{
by \\ JOSEPH PASCOE
}




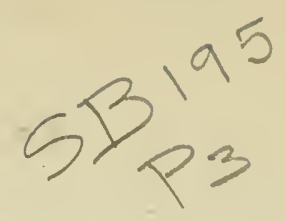

Copyright, 1915 by JOSEPH PASCOE

(C) Cl.A420177

JAN -31916

no! 


\section{PREFACE}

A small cause or neglect often has a great effect.

The experience the author has had with Silos and Silage, since the year 1889 , no doubt will prove interesting to many, as well as a source of profit.

The intentions are to give this information in as brief a form as possible by eliminating all irrelevant matter, at the same time including nothing but what has been experienced by many silage feeders.

The author lays no claim to the origin of silos and silage. What he knows regarding it, he owes to others. He has, upon various occasions, taken whole passages from other writers to prove his claims, without fearing the accusation of plagiarism.

The feeding value of good, sweet silage and the profits derived from the same are no longer questioned, they are recognized facts. But, in showing the profits obtained from feeding good silage, we should be careful and not overlook the possible loss which is the result of feeding spoiled silage. If the author has been successful in making this plain, he will feel repaid for his labor.

THE AUTHOR.

November 24, 1915. 


\section{CONTENTS}

CHAPTER I. HISTORY.

CHAPTER II. ENSILAGE OR SILAGE.

CHAPTER III. AMOUNT OF SILAGE TO BE FED DAILY.

CHAPTER IV. WHEN TO FILL THE SILO.

Corn.

Frosted corn.

Green corn.

Shocked corn.

Fodder corn.

Corn and cow-peas.

Kafir-corn and sorghum.

CHAPTER V. HOW TO FILL THE SILO.

CHAPTER VI. FEEDING VALUE COMPARED

Corn Silage.

Kafir-corn silage.

Sorghum silage.

CHAPTER VII. THE DAIRY COW AND HER TREATMENT.

CHAPTER VIII. WHICH SILO IS THE BEST FOR MY USE? 
CHAPTER IX. THE SILO DOOR.

CHAPTER X. SPOILED SILAGE AND ITS EFFECTS.

Rotten Silage.

Moldy silage.

Sour silage.

(the effect on horses.)

(the effect on cattle.)

CHAPTER XI. FROZEN SILAGE.

The loss.

The effect on milch cows.

The effect on beef cattle.

The effect on sheep.

The effect on horses.

CHAPTER XII. ALFALFA AS A FARM PRODUCT.

Why we need alfalfa.

Alfalfa a poor weed fighter.

Alfalfa on the farm.

Alfalfa as a hog feed.

Alfalfa as a hay crop.

CHAPTER XIII. TECHNICAL TERMS DEFINED.

CHAPTER XIV. THINGS TO BE REMEMBERED. 


\section{CHAPTER I.}

\section{HISTORY.}

SILO (Latin-Sirus, a pit). A place to store green forage, and should be both air- and water-tight. To obtain the best results, a silo should be not less than twice as high as it is wide and of a cylindrical form.

Silos are of great antiquity, and are traceable as far back as Euripides' time, Theophrastus and others; and are also found in the records of various ancient nations. Silos are still in use in Syria, Turkestan and parts of Africa.

Mr. Mills, of New Jersey, was the first to introduce Ensilage or Silage in the United States, and by a system within the reach of most farmers, he kept one hundred twenty cattle and twelve horses for seven months on the product of thirteen acres. In 1878 Professor Caldwell, of Cornell University, packed short-cropped and straw-covered green fodder in a triangular heap, fifteen feet long and six feet high, rendered air-tight by one and one-half feet of earth. In this way green fodder was kept available for a year. It was not long before bricks and mortar, stone, cement and wood took the place of earth, and now the system is extensively practiced by the better class of farmers.-Warner.

Mark Lane Express recites that the use of the silo in one form or another dates back to one of the earliest Latin writers, who refers to subterranean vaults or silos, wherein the ancient Romans preserved green forage, such as grain and fruit, for winter use. The Mexicans have practiced the system for centuries. 
Samuel Fraser, Professor of Agronomy, Cornell University, recites, in part, that in $1875 \mathrm{Dr}$. Manley Miles, of Michigan, and in $1876 \mathrm{~F}$. Morris, of Maryland, also introduced the system into the United States. Many extravagant claims were advanced in its behalf by early enthusiasts and the lack of knowledge led to many failures, so that the progress made was small for some years. In 1882 but ninety-two farmers could be found who used the silo in the United States. The work of Professors McBryde and King, of the Wisconsin and other Agricultural Experimental Stations, made the position of the silo and silage secure.

In ancient times any form of an excavation, regardless of shape, was considered a silo. Subterranean vaults, holes in the side of a cliff, a dug-out, but possibly the most commonly used was the trench, which was made long, narrow and deep. This, after being filled with forage and green fodder, was covered usually with a coating of straw, tramped well; then it was covered over with earth to a sufficient depth to prevent freezing or to allow the air to come in contact with the enclosed ensilage. These antiquated forms of silos were discarded and replaced by the more modern silo of today.

Thus one can catch at a glance some of the changes and improvements of the SILO, but is left to draw his own conclusion as to the inconvenience experienced by the ancient silo users, when he compares them with the improved silos which are in use at the present time; and still each year brings forth a newer and more perfected idea in the silo world.

The writer is frank in saying that the acme, the climax of silo perfection, is still a problem which the future must solve. 


\section{CHAPTER II.}

\section{ENSILAGE OR SILAGE.}

Ensilage or silage is green fodder or forage kept in a succulent state, and is the natural condition of preservation by the exclusion of air, where it undergoes certain changes.

It is very essential that all feeders and silage users familiarize themselves with the facts which are set forth in this book, and, if the same are complied with, nothing but the best grade of ensilage may be expected. There are no substantial arguments at the present time against the feeding value of good, sweet ensilage. All those who feed ensilage claim it to be not only the cheapest, but the richest, juiciest and most nutritious food known for stock until it can be turned out on rich grass pasture.

Silage Crops are principally corn, Kafir-corn, sorghum, alfalfa, clover, millet, cow-peas, soy-beans, sugar beets, oats, and even weeds and thistles. All of these when properly harvested make good silage.

It might be well to remember that any green forage can be mixed with the above mentioned crops with good results. This is very clearly shown where corn fields which grow an abundance of weeds (wholly due to neglect and lack of cultivation), such as sunflowers, fox-grass, etc., and harvested with the corn, then placed in the silo, where it undergoes the fermenting process, after which this mixture is fed to the stock with good results. While the writer does not claim this mixture to be the very choicest grade of ensilage, he does wish 
it to be understood that all such weeds bearing seeds that go through this process of fermentation will never germinate again and cause further trouble by growing when they are hauled back on the farm in the form of manure.

Professor Robertson, of Canada, has written some very interesting articles on this subject, and has made various experiments along the line of ensilage mixture, making use of Indian corn, sunflower seed heads and horse beans.

The principle back of the practice is to furnish a feed richer in protein substance than corn, and thus avoid the purchase of large quantities of expensive protein foods, such as bran, oil meal, etc.

Ontario Experimental Station found they could save $\$ 63$ on every $\$ 200$ invested in feed if they used corn silage in preference to hay in feeding cattle.

The Mississippi Experimental Station found corn ensilage in the south the most economical means of producing milk, butter and beef.

The Kansas Experimental Station not only produced beef cheaper with silage in the ration, but also the silage-fed steers sold at a higher price on the market than did the dry-fodder steers. They found corn silage when put in the silo would keep for five or six years and retain its feeding value.

The seasons are so uncertain that there is hardly a year that certain parts of Kansas, Oklahoma and western Nebraska are not hard pressed for cattle feed, due to the effect of drought or hot winds, which have been known in two days' time to burn all vegetation to a crisp, leaving the affected districts in an almost destitute condition. 
The better class of farmers has become educated to the feeding value of ensilage, and about the time the hot windstorms are due, he immediately starts his corn binder and mowing machines, harvesting not only his own crops, but gathers all vegetation and forage that grows on highways and byways, for the purpose of turning it into ensilage, thus providing feed for his stock during the winter. The farmer who is negligent in this matter and does not follow the regular custom, which guarantees feed for his stock, ships his cattle out of the country poor and in a half-starved condition, and is very willing to take whatever he is offered for them. This means failure and poor management.

Sure feed crops and live stock to consume them should be considered first, and cash crops second, when attempting to forecast the net financial outcome of the season's operations on any farm. Ensilage seems to meet with these qualifications. It is the balance wheel of trade. 


\section{CHAPTER III.}

\section{THE AMOUNT OF SILAGE TO BE FED DAILY.}

Different Kinds of Stock.

Pounds.

Daily Ration

\section{BEEF CATTLE.}

Fattening beef cattle, $11 / 2$ to 2 years old.........20 to $30 \mathrm{lbs}$.

Closing the feeding period (more corn and less silage) 15 to $25 \mathrm{lbs}$. SHEEP.

Fattening sheep (must be fresh sweet silage)....... 3 to 4 lbs.

Fattening lambs (must be fresh sweet silage)......2 to 3 lbs.

Wintering breeding sheep (fresh silage and warm barn) 3 to 5 lbs. CATTLE.

Wintering breeding cows (fresh silage and good oat

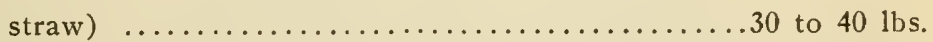

Wintering calves and yearlings (fresh silage, little corn) 15 to $25 \mathrm{lbs}$. MILCH COWS.

Fresh silage, good water and warm barn.......... HORSES.

Matured animals (depending on their size)........20 to $40 \mathrm{lbs}$. Mares (with sucking colts, peck of silage, twice a day).

Weaning colts (one gallon twice a day).

Mules, feed same as horses (one gallon to peck at a meal).

CAUTION. All animals should be fed lightly, until they become used to silage. 


\section{CHAPTER IV. WHEN TO FILL THE SILO.}

It is very important that one should know the proper time for filling the silo, as well as to know how to fill the silo, so that the best results may be obtained, thereby eliminating the possibility of having low grade if not spoiled ensilage.

\section{Corn.}

The proper time for corn to be placed in the silo is when it has reached the highest degree of maturity. This means when the corn has become hard and glazed, with as many green leaves on the stalk as possible. The condition of the corn is apparent by the appearance of the leaves. When the leaves begin to turn brown and die next to the bottom of the stalk it is a sure and unfailing sign that the corn is ready for the silo. Corn cut and placed in the silo at this period needs no water, as there is plenty of juice in the stalk to create natural preservation through fermentation.

\section{Frosted Corn.}

Frosted corn or corn which has been struck by the frost, if left standing too long before placing in the silo is not materially damaged for silage purposes, but if it is left to stand for any great length of time it becomes dry and woody. It is of extreme importance to then dampen it with water. If this is done at the time of filling the silo, one can expect a very good grade of 
silage, which can be fed with perfect safety, without experiencing any unfavorable results.

\section{Corn Siloed Too Green.}

Corn that is cut and siloed too green, that is, when it is still in the milk stage, works an unnecessary hardship, as it acts as a laxative on the cattle, causing them to scour. It is too washy, - as a feed there is not body enough to it. When fed in winter time the cattle show the effect of cold weather by chilling very easily. One who has made the mistake of harvesting the corn too green can greatly overcome these results by sprinkling over each ration of silage a light covering of oats. This will have a tendency to check the scours, so that the feed is not an entire loss.

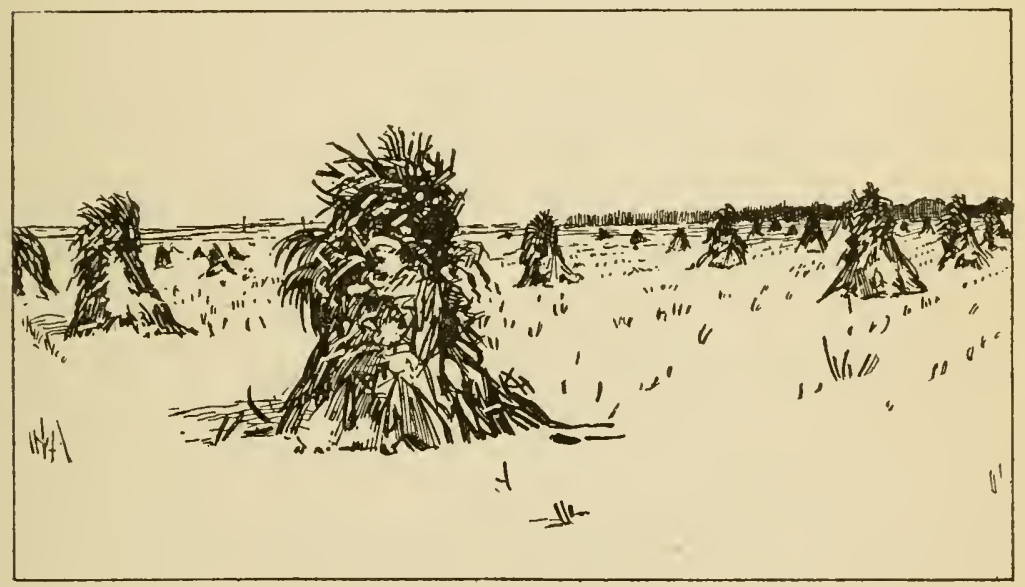

\section{Corn Siloed from the Shock.}

Corn can be taken from the shock after it has stood in the field four or five months, and if rightly handled it will make very good silage. This has been accomplished by cutting the fodder very short (or cut fine, 
as it is dry, woody and fibrous), and mixing it with alfalfa, supplying plenty of water. During the time of fermentation the juice from the alfalfa acts on the corn in such a manner that the coloring of the corn is to a large degree reclaimed. The aroma and the feeding qualities are nearly what they would have been had the corn been cut in a ripened condition.

\section{Corn Mixed with Cow-Peas.}

Possibly the best and choicest feed known to silage users and feeders is made by mixing cow-peas, or some legume plant, with corn properly matured. In this mixture are all the elements necessary to make the very choicest feed and it is eaten ravenously by cattle, horses and hogs. The odor is an appetizer within itself. Corn and alfalfa, the two standard feeds, mixed has made a wonderful record when fed in this manner.

\section{Fodder Corn.}

Fodder corn is usually planted very thick, so as to produce a greater amount of forage, but has very small ears or nubbins, if any at all. Since the fodder is minus the richness of the ears, it has been demonstrated in various communities throughout the middle states, that by mixing this fodder with alfalfa, clover or any legume plant, passing it through the ensilage cutter as it goes in to the silo, where it undergoes the changes known as fermentation, it is rendered into a very desirable feed, especially for dairy cattle and young stock. This same mixture will also apply to Kafir-corn or feterita, both of which are known for their heavy foliage.

\section{Kafir-Corn and Sorghum.}

The proper time for siloing Kafir-corn or sorghum, as is true with all other crops for the making of good 
silage, should be when practically matured, with the stalks still filled with sap. Silage feeders are unanimous regarding the results and profits made from the feeding of such silage.

It is not the good silage, but it is the spoiled silage that does not meet with their endorsement and approval. Such spoilage is largely due to neglect and the lack of knowledge of the proper time to harvest the crop, and the proper care that ensilage must have in order to retain its feeding value. This subject is further discussed under the heading of "Spoiled Silage and Its Effects," which please read. 


\section{CHAPTER V.}

\section{HOW TO FILL THE SILO.}

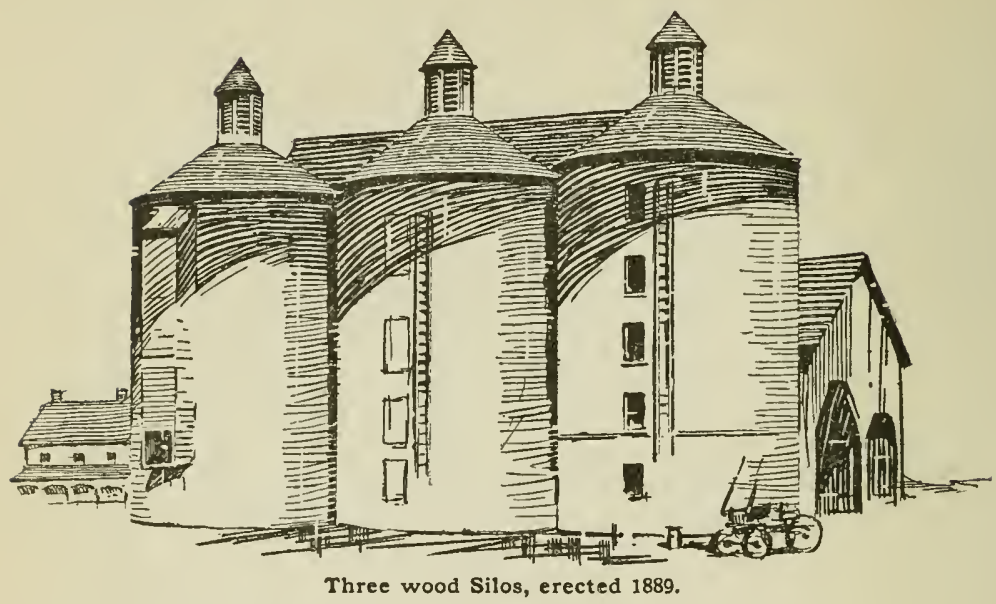

$\left.\begin{array}{l}\text { State of Nebraska, } \\ \text { County of Dodge. }\end{array}\right\}$ ss.

I, Oliver S. Taylor, of Fremont, Nebraska, first being duly sworn upon oath, depose and say that I was in the employment of the Standard Cattle Company, in the year 1889, during which time these three silos were erected, as shown by the accompanying picture. With a few repairs to the roof and doors the silos apparently are in as good condition as they were at the time of their construction.

$$
\begin{aligned}
& \text { (Signed) O. S. TAYLOR, } \\
& \text { Ex-foreman and cattle feeder. }
\end{aligned}
$$

Subscribed and sworn to by the above named O. S. Taylor before me and in my presence, this, the eighth day of January, 1914, A. D.

F. DOLEZAL,

Notary Public in and for Dodge Co., State of Nebr. 
It was in the year of 1889 , on the Standard Cattle Company's ranch, near Fremont, Nebraska, when the writer received his first experience in the art of silo filling and the feeding of ensilage. At that time it was wholly an experiment with all of us, consequently it required several years to learn the details of silo filling to obtain the desired results. The first fodder was cut in long lengths, possibly two inches if not longer, but, when the time came for feeding the silage, it was found that the cattle would eat every morsel, except the hard fibrous pieces of corn stalks, which would be left in the troughs. At the time of the next feeding these hard butts of cornstalks would be shoveled out of the feeding troughs and fresh silage again fed to the cattle.

This process went on for two years. The third year the silos were filled, the fodder was cut in much shorter lengths, possibly not to exceed one inch. Upon feeding this silage it was found that the whole ration would be eaten, butts and all. This led to the conclusion that fodder should never be cut in lengths to exceed one inch and less if possible.

There are two reasons why fodder should be cut fine. First, the cattle will consume all of the silage, cleaning their troughs at each feeding, and thus none of the silage goes to waste. Second, the silage will preserve better, and pack more closely in the silo, which is necessary for proper preservation of the silage through the exclusion of the air.

The art of filling the silo correctly is a matter of no small importance, and when the time comes for feeding, the ensilage will tell the story better than it can be described in a book, if it has been properly prepared.

One has no more right to condemn the silo for the 
loss of his feed than he has in condemning a bank for the loss of his money. The fault is not in the silo, neither is it in the bank. It is the man inside of the silo or bank, who has been entrusted with the account.

The filling of a silo requires two or three good men inside who are personally responsible for the condition of the silage, as it will appear at the time of feeding. The surface of the silage must be kept as nearly level as possible. Should the fodder be left to form piles and not evenly distributed, mold spots will appear at the time of feeding or when the silage is taken out. The pressing or tramping of silage should be done with care and precaution. The more silage is tramped the better, especially next to the silo wall. This part of the silo must be well tramped or there will be a ring of rotten silage form around the entire silo. The fodder as it comes in to the silo through the blow-pipe should be placed where needed and leveled wholly by the aid of the distributer, without forking it about in the silo. The least a fork is used the better, as the fork will pick up the fodder, allowing the kernels of corn or grain to remain in one place without being properly mixed. This should be observed carefully and guarded with care.

The silo being filled, or nearly so, there should be enough chaff or straw (oat straw preferable), well saturated with water, passed through the silage cutter to cover the top to a depth of about one foot, then tramp well, and over this coating of straw sprinkle a couple bushels of oats. The heat of the silage will cause the oats to sprout and grow, thus sealing the silage so that there will be none of it spoiled when the silo is opened for feeding. This method is very simple and equally effective. There has been and possibly always will be 
a great deal of speculative talk regarding the cost of filling a silo. Some claim "It costs too much to fill a silo," etc., while others claim that "the filling of a silo is no more expensive than putting up so much hay." Now, what is the reason for those two contradicting statements? Looking at it from various angles it is simply this. One thinks he knows how to handle men and machinery, but doesn't, while the other knows how to handle men and machinery, and does it.

The information and facts that have been gathered from Experimental Stations in every section of the United States, unqualifiedly shows that a man who has a silo to fill and really knows how to handle his help can, with the force of men usually obtained from three neighbors in the same community, fill their own silos without any additional help, thus storing away sufficient feed for their cattle at a cost not to exceed 75 cents per ton, and hundreds of farmers claim the cost not to be over 50 cents per ton. 


\section{CHAPTER VI.}

\section{FEEDING VALUE OF CORN, KAFIR AND SOR- GHUM ENSILAGE COMPARED.}

The Kansas Agricultural College finished in May the most important feeding demonstration that has been made in the past twenty-five years. It was made to determine the comparative feeding value of ensilage made from corn, Kafir-corn and sorghum. The experiment was made with both beef and dairy cattle, and showed with both that, pound for pound, the silage from all three crops had practically the same feeding value. It proved that the best crop to grow for silage was the one that, where grown, would make the largest tonnage per acre. These demonstrations benefit a larger area and a greater number of farmers than any others that have been made for years. The test with beef cattle was made with Hereford calves, ten in each lot.

Below is the record made:

\section{Ration.}

$\begin{array}{lccc} & \text { Lot } 1 & \text { Lot } 2 & \text { Lot } 3 \\ \text { Original value ...... } & 7.80 & \$ 7.80 & \$ 7.80 \\ \text { Value of the lot.... } & 325.40 & 321.65 & 333.90 \\ \text { Original weight } \ldots . . . & 4,172 \text { lbs. } & 4,124 \text { lbs. } & 4,281 \text { lbs. }\end{array}$

Feed Consumed.

Corn silage ....... 27,431 lbs.

Kafir silage ............ 30,865 lbs.

Sweet sorghum silage ........... 30,855 lbs.

Cotton seed meal .. 927 lbs. 927 lbs. 927 lbs. 


\section{Details.}

Final weight $\ldots \ldots .5,700$ lbs. 5,751 lbs. 5,865 lbs. Total gain ........ 1,528 lbs. 1,627 lbs. 1,584 lbs. Average daily gain.. $\quad 1.1 / 2$ lbs. $1.62 \mathrm{lbs} .1 .58 \mathrm{lbs}$. Cost of feed ...... \$55.05 \$54.96 \$54.94

Daily cost by head.. $0.055 \quad 0.0549 \quad 0.0549$

Cost of grain...... $3.60 \quad 3.37 \quad 3.46$

$\begin{array}{llll}\text { Value hundred weight } \quad 7.50 & 7.60 & 7.50\end{array}$

Final value by lot... 427.50 $437.07 \quad 439.87$

Profit by lot ..... $47.05 \quad 60.46 \quad 51.03$

Kafir silage made $28 \%$ more profit than corn silage, and sweet sorghum silage made $8 \%$ more profit than corn silage. Corn silage has usually produced better gains than either Kafir or sorghum silage. The reason found was that the Kafir-corn and sorghum-made silage for this feeding test was cut when the seeds were practically matured, but while the stocks were still green and filled with sap.

Dairy cattle. This test covered a period of two years, when it was found that silage made from corn, Kafir-corn and sorghum were practically equal, pound for pound, for milk production. 


\section{AGRICULTURAL EXPERIMENT STATION, COLUMBIA, MISSOURI.}

Bulletin No. 112.

\section{Corn Silage for Fattening Two-Year-Old Steers.}

H. O. Allison.

With the introduction of corn silage as a feed for fattening cattle, during recent years, new questions concerning this branch of agriculture have arisen. Perhaps those relating to the relative value of corn silage and its proper combination with other feeds are of first consideration. It is recognized that all of the arguments for and against the use of this feed in fattening cattle are not to be found in a study of its food value alone, yet without doubt they are the prime importance. The Missouri Experimental Station has been feeding corn silage to beef cattle for a number of years with success. The results reported herein include those from a test which began in December, 1910, and closed in April, 1911.

It was the purpose of this test: First, to secure data concerning the relative value of clover hay and corn silage when each is used as the only roughage in a ration for fattening two-year-old steers. Second, to compare silage with shock-corn on the basis of approximately equal quantities of dry matter fed in each form. Third, to ascertain the importance of feeding a dry roughage, such as clover hay, in addition to silage. Fourth, to study the value of nitrogenous concentrate when fed in a ration where corn silage was used.

Five lots of two-year-old cattle were used in the trial. Four lots contained five head each and one lot four head. The feeding period lasted for 130 days. The following rations were fed to the various lots. 
Lot 1-Shelled corn.

Linseed Oil meal ( $1 \mathrm{lb}$. to $6 \mathrm{lbs}$. of shelled corn).

Clover Hay.

Lot 2-Shelled corn.

Linseed Oil meal ( $1 \mathrm{lb}$. to $6 \mathrm{lbs}$. of shelled corn).

Corn silage.

Lot 3-Shelled corn.

Corn silage.

Clover hay.

Lot 4-Shelled corn.

Linseed oil meal ( $1 \mathrm{lb}$. to 6 lbs. of shelled corn).

Corn silage.

Clover hay.

Lot 5-Shelled corn.

Linseed oil meal ( $1 \mathrm{lb}$. to $6 \mathrm{lbs}$. of shelled corn).

Clover hay.

Shock-corn (equal quantity of dry matter as Lot 4 received as silage).

Each lot was given all the feed that would be eaten without waste. The proportion of linseed oil meal to shelled corn was the same in all lots where both of these feeds were used.

At the beginning of the test, three pigs were allowed to follow each lot of cattle, in order to utilize feed which would otherwise go to waste. It was decided at the close of the first 60 days that another pig could be added to advantage to each of the first four lots, consequently this change was made. As the number of steers in Lot 5 had been reduced to four head, it did not seem necessary to add a pig to this lot. 
The following is the "Summary of Weights and Gains on Steers and Pigs."

\begin{tabular}{|c|c|c|c|c|c|}
\hline \multirow[b]{2}{*}{$\begin{array}{l}\text { Lot } \\
\text { No. }\end{array}$} & \multirow[b]{2}{*}{ Retion fed. } & \multicolumn{2}{|c|}{$\begin{array}{l}\text { Average weight } \\
\text { per steer }\end{array}$} & \multirow{2}{*}{$\begin{array}{c}\text { Average } \\
\text { gain per } \\
\text { steer } \\
130 \text { days. }\end{array}$} & \multirow{2}{*}{\begin{tabular}{|c} 
Gain on \\
pigs \\
produced \\
per steer \\
$130-d a y s$ \\
(poands)
\end{tabular}} \\
\hline & & $\left|\begin{array}{c}\text { beginning } \\
\text { of experi- } \\
\text { ment } \\
\text { (pounds) }\end{array}\right|$ & $\begin{array}{c}\text { Olose of } \\
\text { experi- } \\
\text { ment } \\
\text { [ponnds] }\end{array}$ & & \\
\hline & 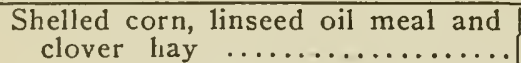 & 946.13 & 1342.13 & 396.00 & 71.86 \\
\hline & Shelled corn, linseed oil meal and & & & & \\
\hline & $\begin{array}{l}\text { corn silage } \ldots \ldots \ldots \ldots \ldots \ldots \ldots \\
\text { Shelled corn, corn silage and }\end{array}$ & 97 & 134 & 365.27 & 74.00 \\
\hline & 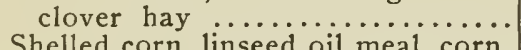 & 962.86 & 1262.86 & 300.00 & 37.80 \\
\hline & silage and clover hay........... & 961.59 & 1371.53 & 409.94 & 60.87 \\
\hline & $\begin{array}{l}\text { Shelled corn, linseed oil meal, } \\
\text { shock corn and clover hay...... }\end{array}$ & 981.91 & 1391.91 & 409.90 & 86.50 \\
\hline
\end{tabular}

\section{COST, SELLING PRICE AND PROFITS.}

Lot 1. Lot 2. Lot 3. Lot 4. Lot 5.

Cost per 100 1bs. gain (pork

$$
\text { credited at } \$ 6.00 \text { per cwt.) .. } \$ 6.46
$$

Selling price per cwt. in Chicago 6.25

Profit per steer after deducting

expense of marketing ..... 2.82

$\begin{array}{rrrr}\$ 6.03 & \$ 6.27 & \$ 5.99 & \$ 6.28 \\ 6.25 & 6.10 & 6.45 & 6.35 \\ 4.79 & 2.09 & 7.41 & 4.08\end{array}$

One of the chief considerations in selecting rations for fattening cattle is the finish produced. The market value per hundred weight is considered the most definite means of judging the relative difference in finish. Consequently, in accordance with arrangements, a committee of expert market judges, who knew nothing of the rations fed the cattle, placed market values on the various lots.

Lot No. 4, which received a ration of shelled corn, linseed oil meal, corn silage and clover hay made maximum gains in live weight, produced the most economical gains, were the best finished and yielded the greatest profit per head. 


\section{The Farmer Proved the Experimental Station to be Correct.}

The following is a letter from one of the best farmers and cattle feeders in the State of Nebraska, and is offered as additional proof that when good silage is fed to cattle, nothing but the best results follow. It is not only gratifying but certainly must be very encouraging to the different State Experimental Stations to know their demonstrations have met with ${ }^{\circ}$ success. When Mr. Mitchell decided to use silage for feed, he immediately opened up a set of books and kept an itemized account of every transaction.

The writer was a member of the committee which audited Mr. Mitchell's books. Both the committee and the bank were satisfied the account which is set forth in Mr. Mitchell's letter had been kept correctly.

$$
\text { Yutan, Neb., June 5th, } 1913 .
$$

To Whom Concerned:

"In the year 1911, I purchased a 100 ton silo, with a guarantee that if the silo did not pay for itself the first year they would take it down and return me every dollar I paid for it. Having confidence in the firm, I gave my order for a silo and immediately opened a set of silo accounts, which resulted in a handsome profit after the cost of the silo had been deducted.

"In 1912, I gave my order for another silo, as my first silo was not large enough. I used the first silo for stock cattle and the 120 ton silo for feeding purposes, and the results are as follows:

"I bought 35 head of feeders; I bought 18 acres of corn at $\$ 15.00$ per acre; I bought $\$ 30.00$ worth of cottonseed meal; I fed $\$ 120$ worth of alfalfa, and after 
deducting commissions, freight, yardage, interest and expense of filling the silo, I find that I made a net gain of $\$ 808.40$ or profit.

"My farm is located about one mile northeast of Yutan, Nebraska, and is sufficiently large to handle about 50 head of cattle the old way of cattle raising, but with the aid of my silos I can handle about 125 head of cattle with less than half of the work and twice the profit. Should any one question the above facts and figures, I extend a welcome to any person to come and see that these statements are backed by the commission merchants, the bank and the scales.

"Carefully submitted, I remain yours truly,

"FRITZ MITCHELL." 


\section{CHAPTER VII.}

\section{THE MILCH COW.}

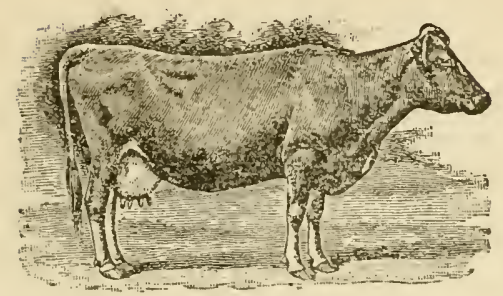

HOUSTON.

The milch cow is the one animal that can be referred to as being the mother of the farm, the producer in every sense of the term. She supplies us with meat, milk, butter, and cheese to eat, and with her hide we are supplied with coats, mittens and shoes to wear. In a word, the milch cow is the farmer's best and most dependable friend, and when he makes a wild speculation and gives as security, the farm, immediately he turns to his friend, the cow, for assistance. She, with all but human intelligence, always stands willing and ready to do her part, she goes down in the records as a mortgage lifter.

She works without ceasing; night and day are the same to her; her labors are never ended until she has accomplished the desired end, even to the sacrifice of her young, which may be driven away to the slaughter block. So determined is she that the debt shall be paid, the mortgage shall be lifted, that she gives up all for her master.

Thus, the extreme necessity and importance of the 
milch cow would certainly solicit full measure in care and humane kindness, regular and liberal feeding of the choicest kinds of nutritious feed, warm, clean and sanitary accommodations in her home, together with gentle treatment. The results of good care and kind treatment means larger production and better quality, which is the cow's method of showing her appreciation.

The example of reciprocity is very beautifully and forcibly set forth in the book of Luke: 6, 38. "Give and it shall be given unto you; good measure, pressed down, and shaken together, and running over. For with the same measure that ye mete withal it shall be measured to you again."

The milk of the cow, which was designed by nature for the benefit of the calf, has been appropriated by man through the avenues of science, whereas dairying is now recognized as being one of the greatest and by far the most independent money-making industries known to man.

There are many very important features connected with this great industry which is the outgrowth of scientific research of dairying. First, the science of utilizing all of the milk produced by the cow in the making of the best grade of butter, cheese, etc., without waste and with the least amount of expense. This is the science of butter-making.

Second. To supply the cow with a milk-producing feed that is best adapted to her conditions for the yielding of the greatest amount of milk at the least expense. This is where good sweet silage plays an important part. You should feed liberally if you want an abundance of milk. The cow has a hard work to perform and it requires all the feed that she can eat, with the least exertion, to give the best results. 
Third. There is an unspeakable profit, which comes from kind and gentle treatment of the cow. She will express her gratitude and appreciation of your kindness, by following you wherever you will permit her. At milking time she will call for you, and through her gentle lowing one can not be mistaken as to her meaning. It has been truthfully said that "a man who is kind to his cattle is always the best neighbor:" However, the cow may be scolded, run down by the aid of dogs, whipped because she failed to find the right stall, kicked or beaten with a milking stool by a cross, peevish keeper, who expects the cow to know more than he does himself (which is very often the case). The cow which has been so punished never fails to "play even." She will hold out on her milk, and if the opportunity presents itself, she will do a good job of kicking.

Now, then, who taught this cow to kick? Who taught her to be ugly and hold out on her milk? Ask her keeper. The cow is exactly as he trained her (this is the negative side of dairying).

A man who has invested his money in lands, cattle, and the necessary equipment to operate a dairy farm, and then misuse or fail to feed his cattle liberally, is certainly very short-sighted indeed.

At this junction the writer wishes to correct a common "hearsay argument" which is afloat and of an erroneous origin, regarding silage and the effect that it is supposed to have on cattle. In some localities it is not an uncommon thing to hear, that, "silage is the cause of cattle losing their teeth." Then again it is given out, that, "silage fed cows will not live over five or six years."

Upon this particular subject the writer has endeavored at various times to trace such statements back to 
their origin, but in each case nothing could be learned except "hear-say arguments," which were without cause or foundation. The reports of silage feeders is quite to the reverse and certainly is very gratifying to know that feeders have proven such arguments to be untrue.

To throw still more light upon this subject, the reader's attention is called to the picture of "Houston," which heads this chapter. This remarkable cow was born in the year 1895 and after serving her time with the Experimental Station of Minnesota, went to make up the car load of cows, which was sold on the market in the year of 1914. This lot of dairy cows had been fed good sweet silage nearly all of their lives, and some of them all of their iives, at least until they had passed the period of usefulness, which was from 17 to 20 years in the service.

Chief T. L. Haecker, of the State University Farm, informed the writer that at the time of selling the above mentioned car load of dairy cows, that, "they were strong, vigorous, healthy cattle and that as far as he could determine their teeth have never been affected in the least by the feeding of silage."

The information that is disclosed in the handling of this car load of cows, is all that is necessary to refute any and all "hearsay arguments" that have ever been made regarding the life of cattle or the loss of their teeth, by the feeding of silage.

The following is an extract from "How to Make Creamery Butter on the Farm," by McLaughlin.

"Feeding the dairy cow, should be done right after milking time, in which case feed flavors largely pass off through channels or secretions other than the milk, and 
are not so noticeable. However, most dairymen and farmers understand this, and there is very little milk spoiled from this cause.

"The feeding of the dairy cow is a very important matter. The composition of feeds is an interesting subject. Most feeds can and should be grown on the farm. The idea of feeding dairy cows simply to dispose of crops is ruinous. The successful idea nowadays is to farm to feed dairy cows.

"Various experts have agreed that corn silage is probably the best and cheapest source of succulence. There should be a silo on every dairy farm, which should be used for the purpose of furnishing this valuable necessary milk-making food during the winter and the dry months of the summer. Corn, oats and barley are splendid for supplying carbohydrates and dry matter to the dairy herd. All these can be raised almost anywhere. So can clover, alfalfa, siveet clover, vetches, cow-peas, soy-beans, and Canadian field peas. Each of these crops are rich in protein and ash. If you will feed hay, made from any of these leguminous crops, together with all of the corn silage that the cow will eat you will find that it will form a balanced ration that will be succulent, and also that the carbohydrates and fats in the corn silage will be balanced by the protein and dry matter in the hay. This will form a splendid ration for cows giving, say, from 15 to 20 pounds of milk per day.

"If you are living in the corn belt, you will find that ground corn and cornmeal is a splendid and a cheap concentrated food. This should, in your case, form the basis of the ration. Such : ration supplies everything necessary except the protein, ash and the necessary variety. It would be well, however, to add such additional 
rations as ground oats, bran, oil meal, dried distillers' grains, gluten feed or some other food rich in gluten.

"Another very well balanced ration, when fed in conjunction with an abundance of corn silage, together with any of the leguminous hays, is a mixture of two parts of ground corn, one part of ground oats and one part of either one of the commercial by-product protein foods.

"The above ration should be supplied to each cow at the rate of one pound each day to every pound of butter-fat that the cow yields each week. This is a very inexpensive ration. Furthermore, it gives the cow exactly what she needs to make the most milk, and the greatest percentage of butter-fat.

"Right in this connection we might say that there is one special time that is best of all for starting the betitering of the feeding methods of the dairy herd. This time is about four to six weeks before the cow is due to freshen. At that time it is best to turn the cow dry and then feed her abundantly. It must be borne in mind at this time that the greatest profits are returned for the feed used in preparing the cow for the work that is to come. It is best that the cow be as high as possible in flesh at the time she freshens. Otherwise too great a percentage of her food will be consumed in maintaining her, building her flesh, strengthening her stamina and not making milk, as it should. It is at this time that the cow that has been well fed with corn silage and good roughage that is high in protein, together with a carefully balanced grain ration, yields the biggest profit to the dairyman. It is then that he begins to pocket the dividends that he has earned by his careful handling of the cow in her dry period. 
"Aside from the fact that corn silage proves one of the best rations for milch cows, it is also one of the cheapest.

"Wherever farmers have tried out this method of feeding the dairy herd, the economy has been at once evident." 


\section{CHAPTER VIII.}

\section{WHICH SILO IS THE BEST FOR USE.}

This subject has been discussed and argued very extensively from the speculative viewpoint. Many specialists abuse by misusing the speculative, to further their interests in a commercial pursuit. The practical, which is the sensible standpoint of view, clearly demonstrates, that any kind of a silo is better than no silo at all, but some silos are much better than others, viz.

1 Some silos will stand better than others.

2 Some silos need more attention than others.

3 Some silos will preserve feed better than others.

4 Some silos will keep feed preserved better than others.

5. Some silos will freeze, while others will not.

So strong are the arguments in favor of the different kinds of silos, that are presented by drilled and trained specialists that, very often, the prospective purchaser is at a loss to deturmine the kind of a silo he really wants, unless he understands something of the merits and demerits of silos. For that reason the above mentioned points have been given, leaving the field open for each man to decide for himself, the kind of a silo that he wants. However, it is very plain that the best silo to have is the silo that will preserve feed the best and will keep the feed best preserved.

Before buying a silo, the purchaser should have a fixed idea as to what he might expect of the silo, then 
consider the elementary features that enter into the construction of the silo that will produce results which will correspond with his ideas. These are all important and very essential; first, the exclusion of air; second, the retaining of heat; third, material that will not retard the curing process (or natural preservation) which takes place during fermentation, is the right kind of material for silo construction, regardless of the cost.

A silo is a mortgage lifter. A silo is the farmer's private bank, in which he owns all of the shares and stocks. So important is it, that the best building material is none too good and by far the cheapest.

A silo that does not meet with the above mentioned qualifications is only a trifle better than the old method of piling chopped fodder in the barn yard, left unprotected, subject to the hazardous conditions of the elements, where it will heat, ferment and undergo all the chemical changes necessary for natural preservation, but the loss is too great. The danger that surrounds the feeding of it to animals is increased many times, instead of being diminished. A silo without an air-tight roof, is like unto a bake-oven without a top. Instead of retaining the heat, it is allowed to escape. A silo should have doors that can be opened and closed at the time of each feeding so as to prevent air-currents, through and within the silo. This subject (silo doors) is fully discussed under that heading, which you should read. 


\section{CHAPTER IX.}

\section{THE SILO DOOR.}

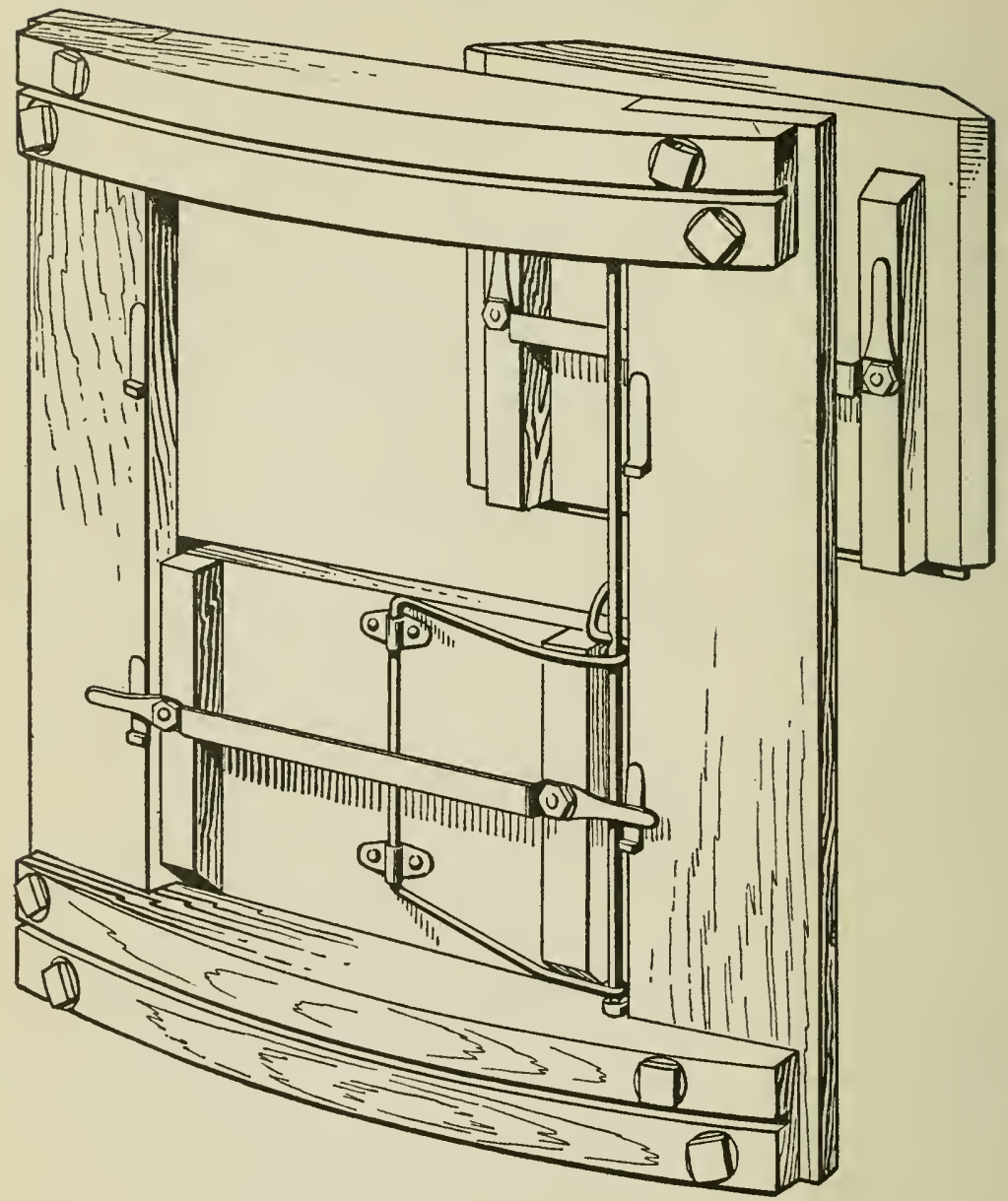

Realizing the need of a more perfect silo door system, the Author of this volume devised and caused to be patented in 1915 the Duplex Silo Door, as shown in the above picture. 
The door is in two parts (or halves) and operates in a single frame, hinged on a vertical pintle, which makes it possible to operate each half-door independent of the other. Thus only one foot of silage need be removed before the door can be opened.

Each half-door is provided with a heavy iron crossbar, forming a perfect ladder from the bottom to the top of the silo. As one ascends the ladder, his weight is never on the door of the silo, but is transmitted through the vertical cleats to the sills of the silo; thus the door cannot sag, pinch, bind or get out of shape. Further information regarding this silo door will be cheerfully given.

During recent years there has been a great deal said, pro and con, regarding silo doors. In fact, some salesmen talk doors to the prospective purchaser more than they do silos. Because of these and other existing facts, the writer proposes to give those who are interested in this subject, the benefit of his twenty-six years of experience, and will endeavor to present the features of the silo door logically and wholly upon its own merits, "hewing close to the line, letting the shavings fall where they will." This will be substantiated by a few citations from the different State Experimental Stations, which will serve, as a basis for the solution of the subject that has an important bearing on airtight receptacles.

It is a foregone conclusion, that, to obtain natural preservation by fermentation, a silo must be air-tight. This is accepted by all as being true, and it is admitted without further discussion that the air causes silage to spoil. Then, where is the argument? It needs no words of explanation. The door of a silo should be kept closed, 
so as to prevent air-currents from coming in contact with the ensilage.

The ordinary size of a silo-door is about 22 inches wide and about 32 inches high, and usually made from material of the same thickness as that of the silo wall. This door when saturated with the juice of silage weighs between 60 and 75 pounds. Thus one can readily understand what a perilous proposition it would be, if not an utter impossibility, to open and close the silo door each time silage was taken out, without having such doors provided with hinges. Is it possible for the reader to imagine himself, unwise as it may seem, clinging to the side of a 30 foot silo, holding to a weak form of a ladder with one hand, and with the other reaching high above his head trying to replace a heavy door in its frame, which he was obliged to force open with a hammer?. What are the results? The door of the silo is left open, thus, exposing the silage to all the hazardous conditions of the atmosphere, thereby, ignoring (through ignorance or neglect) the fundamental principles of preservation, which is, that a silo must be airtight. The air causes silage to mold, rot, freeze and spoil. Yet it is claimed by some that "it is no damage to silage to leave the doors open." But their arguments are absolutely wrong, as wrong can be, and in order to protect themselves in making such a statement, they commit another wrong by saying, "One must feed off 2 or 3 inches of silage daily."

The analysis of this statement is no less surprising. If one is obliged to feed out 2 or 3 inches of silage daily, what is the result? One is feeding 2 or 3 inches of more or less damaged silage, or why are you obliged to feed out so much every day? It is plain to be seen and easily understood that if the door had hinges so that it 
could be closed it would greatly assist in keeping silage from spoiling. Results are what count, and you can't get the best results and have your silage exposed to the air.

To be fair with those who are opposed to the above explanation, the writer will meet them half way, by admitting that during the time which elapses from one feeding to another, the physical appearance of the silage is not so badly damaged that it might be called rotten silage, but from the time that the air strikes it until it is fed the first stages of decomposition have set in and it requires the "chemical test" to prove that it is not as good a grade feed as that farther down in the silo. In many cases the odor is sufficient to show that it is partly decomposed. To verify these claims please note the following citations:

\section{EXPERIMENTAL STATION OF NE-}

\section{BRASKA, BULLETIN, NUMBER 138.}

"When silage ferments, carbon dioxide gas is thrown off. This gas is heavier than air and is transparent. As it is heavier than air, it settles to the lowest place and stays there unless carried away by air currents or some other means."

Again in Bulletin Number 138, under the heading, "Amount to Be Fed":

"As soon as the air comes in contact with silage, fermentation becomes active and the silage soon spoils."

Thus, it would appear that there are two conditions to stimulate fermentation; a fermentation that causes preservation through the juice of silage and exclusion 
of the air, and a fermentation, caused by decomposition of vegetation, at the time of feeding as the results of the air.

\section{EXPERIMENTAL STATION OF IOWA, BULLETIN NUMBER 100.}

"The silo doors should form an air-tight joint. It is desirable to prevent the freezing of silage in the silo during cold weather as far as possible. Freezing of silage is due to the loss of heat: first, through the silo wall; and second, to the air in contact with the feeding surface."

\section{EXPERIMENTAL STATION OF \\ COLUMBIA, MO., BULLETIN NO. 9.}

"Do not feed sour silage, moldy silage, rotten silage, or frozen silage to animals."

The writer takes this method of showing the farmer the importance of keeping the doors of his silo closed, as long as feed is being taken out of the silo. He has also tried to prove that his claims are true by referring to the different Experimental Station reports in the form of bulletins. 


\section{CHAPTER X.}

\section{SPOILED SILAGE AND ITS EFFECTS.}

Every subject of merit will bear investigation from various angles. Many magazines and journals of today have their columns filled up with silos and silage, until they take the appearance of a hand-bill for a department store announcing a big sale. The articles written today are exactly the same as those written ten and fifteen years ago, notwithstanding there are hundreds of new and useful experiments being conducted annually for the purpose of demonstrating some useful discovery. It would seem that those who are endeavoring to champion the good cause of silos and silage, attempting to show the farmer the profits derived from its use, would not leave the farmer in darkness to eke out by experience the amount of his loss, which overshadows all profits, if spoiled silage is fed to his animals. Knowing the need of and the difficulties experienced in obtaining information on this subject, the following has been prepared to aid those who are inexperienced.

Because of the similarity of the conditions and effects which moldy and rotten silage has upon live stock, it is thought best to treat both subjects under one heading.

\section{Moldy Silage.}

Moldy silage is one of the stages of decomposed silage which makes it dangerous to feed to any kind of live stock. It is the direct result of the lack of care and precaution that fodder must have during the time of 
filling the silo. Mold spots will appear any place within the silo where the fodder has been allowed to form piles and not evenly distributed, the surface being left to settle irregularly, which will form air-pockets. The mold spots are the results. If fodder is ensiled too dry, cut in long lengths, without adding water to the fodder at the time of filling the silo, it is possible, if not probable, that mold nodules will form throughout the entire silo. Please read article "How to Fill the Silo."

\section{Rotten Silage.}

Rotten silage may or may not be the direct cause of air-pockets in the silo. However, it is more reasonable to understand the air was not properly extracted through the lack of tramping or packing during the time the silo was filled. Nevertheless, it is a certainty that after the fodder passed through the conditions of fermentation, the air was permitted to come in contact with the ensilage, which was the cause of its rotting, and rendered it worse than a loss for feeding purposes. Rotten silage is more frequently noticed in silos nearest the wall or doors, which is due to the lack of pressing, thus causing the ensilage to settle inwardly and away from the wall or door, forming an air-chamber in which the air has unrestricted circulation.

In order to furnish the best information obtainable on the effects which come from feeding moldy or rotten silage, much time has been spent with veterinary surgeons, college professors, and an extended research of authorities on surgery.

It was learned that the best cure for horses, sheep and cattle that might become affected as a result of eating spoiled silage, lay in the preventive, as all methods of treatment so far have proved of no value. 
The disease from feeding moldy or rotten silage is called "Cerebritis, Cerebro Spinal-meningitis."

\section{Effects on Horses.}

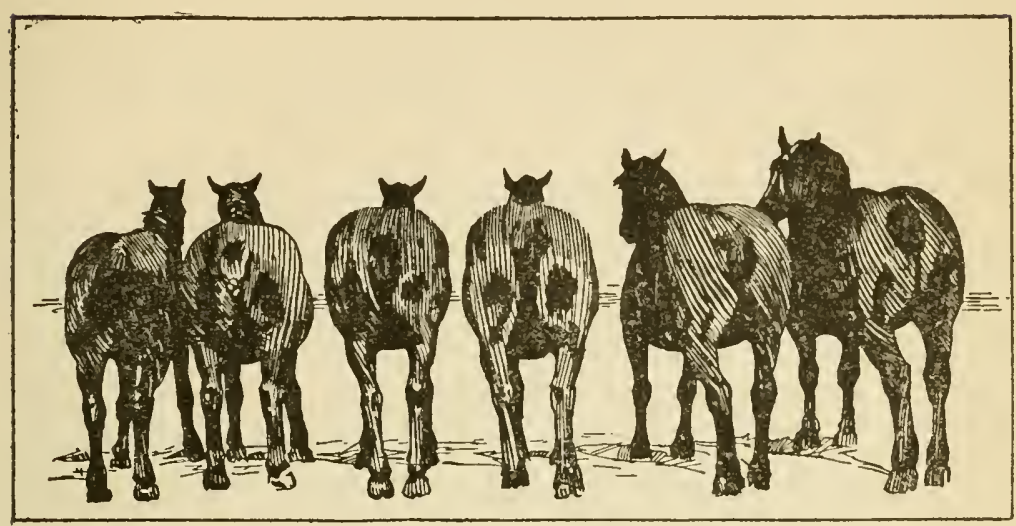

Pure-bred Percherons fed Silage and Hay only, no Corn. W. S. BOLES, Enid, Okla.

The symptoms of the horse are unsteadiness in its walk, weakness, trembling of the voluntary muscles, difficulty in eating and swallowing, delirium, and in most cases death comes to its relief. Others are affected by "mad" or "blind staggers" and the only relief found in many surgical books was a prompt and effective laxative; then waste no time in calling a good surgeon.

\section{Effects on Cattle.}

The symptoms in cattle are the loss of appetite, constipation, weakness, heavy breathing due to the filling of the lung tissues with poisonous gas. They, like the horse, become delirious and in many cases die. Cattle are not affected so easily as the horse, but sheep are affected more easily than either the horse or cattle. Their sickness is of less duration and death comes more quickly.

It is hoped that the reader will not get the wrong 
meaning of this article, and what it is intended to convey. It is the intent of the writer to recognize good, sweet silage, as not only a profit and a benefit in the widest sense of the word, but the cheapest succulent feed known, while moldy, rotten and otherwise spoiled silage is a damage and very dangerous to be used as a feed. This is the chief cause of dissatisfaction amongst silage feeders.

Possibly nothing has ever done more to discourage the farmer in the building of silos than to learn from his neighbor, who has a silo, that he had sickness or suffered a loss in his herd when he was feeding silage. This farmer, who would have been a prospective purchaser of a silo the next year, without knowing the real cause of the trouble, immediately goes on record by saying "No silo for me," and starts a little campaign of his own, simply because the fodder was not properly taken care of, and, too, the feeder did not know of the danger and effects of spoiled silage. The object of this book is to show the profits of silage, by instructing the farmer how to safeguard his interests against a possible loss. 


\section{CHAPTER XI.}

\section{FROZEN ENSILAGE.}

If there is one subject in this book that the writer hopes to make more plain than another, it is the subject of frozen silage, so that the farmer may become thoroughly conversant with the truth and facts which his own experience teach him.

At the present day and age, nearly every magazine or journal in the country has a long, striking article of some kind on the profits and needs of the silo for the farmer, and the good results that he can obtain from feeding good, sweet silage, all of which is correct. Then possibly the very next edition, if not the same one, gives out this startling information, "Silage is not materially damaged by freezing," and finishing the story by citing as reference some party in a distant land, who knows no more about a silo than what he had read through some article, which originated from the same source as the one he, himself, was instrumental in having printed.

Thus, the farmer who is not accustomed to feeding silage takes it for granted that should his silage freeze it is not damaged, so it is immaterial whether his silo has doors to open and close or a roof to prevent freezing. Possibly the next information that he gets is "When silage is frozen dig it loose, pile it in the center of the silo, where it will thaw-out ready for the next feeding, and its feeding value is in no way impaired," and many other statements equally extravagant.

After the farmer has fed a few feedings of frozen silage (or silage which has been frozen and then 
thawed-out), it is he who comes in contact with the mysterious results, and it is he who begins to reflect, and, one after another, those imaginary statements, which he formerly read, are censored and blamed for not only the damaged condition of his feed but for the unfavorable results which are sure to follow.

Many, yes, hundreds of farmers who have experienced the results of feeding frozen silage have been heard to say, "I would give $\$ 100.00$, if I could prevent my silo from freezing," for two reasons. One is, it is an arduous task to pick frozen silage loose, and second, ice water to drink and ice silage to eat do not bring good results when given to any kind of an animal.

Suppose we weigh the above mentioned statements on the scales of actual experience, then compare those results with at least a barn-yard analysis of frozen silage and see if we can arrive at an intelligent conclusion.

\section{The Loss.}

The loss by frozen silage is not necessarily confined and restricted to the few paltry dollars which is represented in the cheapness of the feed, nor should it be construed to mean only a dead animal. But feed of any kind that will deflect the appetite or otherwise impair the normal condition of an animal is, and should be so considered, a loss and poor stuff to feed.

The right way to show the farmer the profit obtained from having a silo and feeding silage, which has been heretofore mentioned, is to safeguard his interests against a loss, which is hereinafter mentioned.

\section{Symptoms of Milk Cows.}

The milch cow, when fed frozen silage, loses its appetite, refuses to eat or drink, becomes bloated. When 
standing it usually holds its head lower than normal, apparently cold, and the loss in the production of milk tells the story.

The milch cow that is fed a ration of silage that has been frozen and thawed-out becomes weakened, and is subject to a severe attack of scours.

\section{Symptoms of Beef Cattle.}

After giving a lot of beef cattle a feeding of frozen silage, they go off from their feed so quickly that there could be no question as to the cause. The animals will refuse to eat or drink, will nose about the feed, but have no appetite to eat. Bloating is very noticeable. The frozen feed which has been eaten begins to ferment and thaw, and a gas forms in the lung tissues, the digestive system has been chilled and is inactive. This may last for a period of two or three days, when the animal either gets better or dies.

Beef cattle which have been fed silage which has been frozen and then thawed-out are subject to severe attacks of scours.

\section{Symptoms of Sheep.}

The sheep, the most delicate and sensitive animal on the farm, poison easily and die quickly. Whole herds of sheep have been affected by a single feeding of damaged silage, frozen, moldy, rotten or soured. They do well on good, fresh silage.

Experimental Station of Columbia, Missouri. Bulletin Number 9, Page 65. "Damaged silage should not be fed to any kind of live stock, but good, fresh silage is a fine feed for sheep. If fed judiciously, they like it, and will thrive on it in the winter time as if they were on good pasture in the summer." The bulletin gives a very 
interesting explanation of what might be called damaged silage or spoiled silage as follows: "Do not feed sour silage, moldy silage, rotten silage or frozen silage." This bulletin refers to the feeding of silage to all kinds of live stock. The citation regarding sheep is here given, as whatever a sheep will thrive on any other kind of an animal will do well on.

\section{Symptoms of the Horse.}

The horse after he has had a feeding of frozen silage becomes sick more quickly than the milch cow or the beef. He staggers and circles in his walk, he lays down and gets up very frequently. When laying down he throws his head backward. His kicking and attempting to roll over shows that he is in much pain or cramps. Drenching with a quart of sweet milk, or a pint of molasses mixed with warm water or drenching with a good laxative has been known to give relief.

The cure that is sure, lays in the preventive, which is a safeguard against the loss.

The reader of this article will now sum up all of the evidence which has been introduced and judge accordingly, determine for himself, whether or not "silage is not materially damaged by freezing" or "when silage is frozen dig it loose, pile in the center of the silo, where it will thaw-out ready for the next feeding, and its feeding value is in no way impaired." 


\section{GRAND CHAMPION STEERS FED SILAGE.}

Fifteen silos, ranging in capacity from 200 to 250 tons, will be in use this year on the ranch of Henry B. Johnson of Chickasha, Okla., the most important cattle feeder in the Southwest and one of the best known cattlemen in the country. Six silos were filled on the ranch last year and steers made such big gains on silage combined with other feeds to make a balanced ration that Mr. Johnson decided to treble his silo capacity. Among the steers which were fed silage last year was a herd of 30 Aberdeen Angus cattle, two-year-olds, which were declared grand champions at the Fort Worth Fat Stock Show last March and which were bought by Swift \& Co. for $\$ 12$ a hundred pounds, the highest price ever paid in the Southwest. Their average weight was 1,360 pounds and they dressed 63.90 per cent. They came from the herd of James W. Knox of Jacksboro, Texas. Mr. Johnson's cattle have won sweepstakes and grand championship prizes for the last six years and he holds the record for top prices at four markets-Kansas City, St. Louis, St. Joseph and Fort Worth. His steers are known the country over and command a premium.

Since feeding silage Mr. Johnson has increased his profits $\$ 10$ on each steer he sends to market. His investment in the six silos is $\$ 3,300$. He fed the contents to 1,200 steers, on each of which he made about $\$ 10$, leaving him a profit of $\$ 10,800$ or a net profit of $\$ 7,500$ after the silos had been paid for. He says there is no other way to make such a saving feeding cattle. The silo capacity of the Johnson ranch, with the completion of the nine new ones, will be 3,510 tons, and this will be mostly Kafir and corn silage and will be fed to some 
3,000 to 4,000 steers this winter. There are 25,000 acres in the Johnson ranch, of which 400 are alfalfa.

\section{Erected Silos in a Hurry.}

Mr. Johnson erected his silos late and had to hurry to fill them. Into the first two he put corn and into the last four Kafir, Milo and cane. The feed kept well and was started feeding October 4th. To one pen of 300 two-year-old steers he fed a ration of 25 pounds corn silage and 4 pounds of cotton seed meal for sixty days. They were Hereford cattle and did well. A herd of Aberdeen Angus two-year-olds were also fed the same ration. A bunch of white face yearlings and a herd of Angus yearlings were also fed about the same ration. At the end of sixty days all the corn silage was used and Kafir and cane was fed, to which was added a ration of 8 pounds of corn meal and 6 to 10 pounds of cotton seed hi1ls and the cotton seed meal was increased to 5 pounds. The first shipment of red cattle went to Kansas City and brought $\$ 8.10$ a hundred and averaged 1,266 pounds. The next shipment weighed 1,178 pounds and brought $\$ 7.90$ and a third lot weighed 1,164 pounds and brought $\$ 7.80$ a hundred. A fourth shipment to Kansas City weighed 1,160 pounds and brought $\$ 7.65$. The black two-year-olds also went to Kansas City, where they brought $\$ 8.00, \$ 7.90, \$ 7.80$ and $\$ 7.65$, with an average weight of 1,150 pounds. The yearlings sold for an average of about $\$ 7.75$ and averaged 900 pounds in weight. These cattle were not weighed in the feed lot, but $\mathrm{Mr}$. Johnson and his trained assistants guessed the yearlings to average about 700 pounds and the two-year-olds about 850 pounds. Comparing his feed bills with past year's, when hulls and cotton seed meal, ground corn and alfalfa hay were fed, showed that the expense of fattening cattle had been reduced 
$\$ 10.00$ a head. Mr. Johnson, as a result of this experiment, considers corn silage one of the richest feeds he ever tried. He is also well satisfied with Kafir, especially since it can be depended upon to make an annual crop in spite of adverse weather conditions.

\section{His Silage Ran Out.}

Toward the close of the feeding period Mr. Johnson found that he did not have sufficient silage to continue feeding at the rate he had started and he was compelled to cut down the proportion of silage about ten pounds a head. Years of experience in feeding cattle, however, convinced him that it was the silage which was making the big gains in the weight of his steers and this year he will be prepared to fatten fully three times as many steers as last winter. Mr. Johnson believes in cutting his silage into as small pieces as possible, not larger than $1 / 4$-inch in length. This enables the cattle to eat every particle of the feed and not waste any. He has installed a 40-horsepower Ross silage cutter and blower. This stands in his big steel shed when not in use instead of out in the open to rust as so many farmers treat their machinery.

"No farmer, big or small, can afford to be without a silo," Mr. Johnson told the writer. "It is the only way to feed cattle at a minimum of cost. Any other way will cost a man just from $\$ 8$ to $\$ 10$ a head more. Silage increases the flow of milk at least half and young cattle will make faster growth on silage than on any other kind of feed."

Mr. Johnson keeps books on every steer on the place. He is a very busy man, being a director in the First National Bank of Chickasha and having many interests throughout the state. He is also president of 
the Chickasha Milling Company and a director in the Chickasha Cotton Oil Company. He is considered to be the wealthiest man in the county. He once handled cattle on the range and is an adept in roping a steer. He personally superintends every piece of work on his large ranch and is in the saddle or in his automobile early and late giving orders or making inspections. His home in Chickasha is one of the finest in the state, but he is loyal to his humble home in what was the old Indian Territory.

"A farmer can't expect to succeed if he does not watch the leaks," is one of his favorite sayings. As an instance of his quickness in stopping leaks may be cited his erection of a feed mixing shed because he noticed that much feed was being blown away by the high winds. This was especially true of cotton seed meal. He says enough meal is wasted in that manner on dozens of farms to rob farmers of their profits on a herd of cattle. He says there is no limit, apparently, to the number of cattle that can be fattened on his ranch, except the inability to get young stock enough. He is a believer in high grade stock and pure breeds and has no use for "scrubs," which he says can never make anyone any money.

While the erection of nine more silos on his ranch will keep him busy for a while, he says he probably will erect more just as soon as he is ready to handle more cattle and has raised enough feed to carry them through the winter. In the old cattle days it took eight to ten acres of grass to keep a steer in feed. If this land were put into Kafir one acre probably would keep ten steers, provided the season was favorable.-The Southwest Trail. 


\section{CHAPTER XII.}

\section{ALFALFA AS A USEFUL PRODUCT.}

Alfalfa is comparatively a new crep in the United States, but is destined to come rapidly into general use. There are few farmers whose profits would not be increased greatly by raising alfalfa. Every farmer should aim to produce, as far as possible, all his foodstuffs on his own farm.

During the last few years, the area devoted to alfalfa has greatly increased in the region west of the Missouri river, and it is certain that there will be an equally rapid increase throughout the eastern part of the United States.

Many of the attempts in the past to grow alfalfa in the humid regions have failed, but with our present knowledge of the requirements of the crop there will be little, if any, more trouble in securing a stand of alfalfa than of clover. However, the methods followed in securing a catch of clover will almost certainly fail with alfalfa.

Do not be hasty in concluding your stand is poor. It frequently shows up to better advantage the second year. In case the stand is not satisfactory, it is generally better to use the same ground for a second trial than to take a new field.

Why we need alfalfa. There is no combination of feeds so economical for the production of pork, beef, butter and eggs, and for growing animals as corn and alfalfa. Neither will give the best results alone. We need alfalfa because it balances up the corn ration and 
saves the large waste of starch which always takes place where corn is fed alone. We need alfalfa because we can in this way grow on our own farms the protein more profitably than we can buy it in feed stuffs. We need alfalfa because it feeds the soil and enables us to grow larger crops of corn and oats. We need alfalfa because it produces, on an average, double the feed value per acre of clover or any other forage crop.

Alfalfa a poor weed fighter. Alfalfa, when small, grows slowly, and is not a good fighter, that is, it cannot compete with weeds, and especially with crab grass and oats, wheat or barley, as the case may be, and when these are cut off, the alfalfa is in no condition to compete with fox-tail and other weeds during the dry weather of July and August. When sown in the spring without a nurse crop, there is a constant struggle with the weeds during the entire season, and the weeds generally come out best, leaving a poor, patchy stand of alfalfa.

Manure and inoculation most important. There is no one thing that will do more to insure success than' the application of twelve to fifteen loads of good barnyard manure to the acre. Land well enriched with manure is almost certain to produce a good stand of alfalfa. Lime can almost always be used to good advantage, and the benefits are especially striking on compact clay soils that have been cropped for many years.

In regions where alfalfa has not been grown, it is found to be very beneficial to inoculate the ground by sowing three or four bags of soil secured from a field where alfalfa has been grown for a number of years; or, where it is more convenient, artificial cultures such as "nitragin," "farmogerm," etc., may be applied. Where alfalfa has not been grown before it may make 
the difference between success and failure. The application of acid phosphate or fine ground bone meal is always beneficial, but cannot be regarded as absolutely essential to success.

Well prepared seed bed essential. A well prepared, firm, solid seed bed, plenty of good barn-yard manure and summer fallowing to kill the weeds, are most important. Lime? Yes, one to two loads per acre, and by all means inoculate. Ground too wet for corn is not suited for alfalfa.

Alfalfa seed may be either drilled, or sowed, broadcast and harrowed in, or even disked in, especially if the surface of the ground is dry. The seed can be more evenly distributed if one-half is sown in one direction and the other half sown at right angles. It is always a good plan to sow the seed a little thicker around the edges of the field, as this portion of the field is more subject to injury from insects, fox-tail, etc.

While it is the custom in the humid regions to sow twenty pounds to the acre, ten to twelve pounds of seed per acre are sufficient. If evenly distributed, this will give from fifty to sixty seeds for every square foot, while one thrifty plant to the square foot is sufficient.

Alfalfa on the farm. Remember that alfalfa can be grown on your farm. It is no more difficult to grow than clover and is more hardy when once established. It adapts itself to all kinds and conditions of soil and climate. Alfalfa produces three and sometimes four crops per year, in the corn belt. Alfalfa is the cheapest source of protein. When wheat bran is worth $\$ 22.00$ per ton, good alfalfa hay is worth $\$ 20.00$ to $\$ 22.00$ per ton.

Alfalfa is the most enriching crop we have, and 
insures larger yields from the crops that follow. When a good stand is once secured it lasts for four or five years in the humid regions, and much longer in parts of the west. Alfalfa can be fed to all kinds of animals and has no superior as a hog pasture. Alfalfa adds humus to the soil and resists drought better than other crops.

As hay alfalfa has no equal. It is rich in protein, the very thing in which our corn and most other crops are deficient. Therefore, it balances up the ration and saves the purchase of high-priced feeds.

This article on alfalfa certainly carries with it a great deal of weight, as it was prepared by one of the best, if not the best agriculturists in the United States, Prof. P. G. Holden, who formerly was connected with the Experimental Station of Iowa. 


\section{CHAPTER XIII.}

\section{TECHNICAL TERMS DEFINED.}

Albuminoids. A group of substances of the highest importance in feeding farm animals, as they furnish the material from which flesh, blood, skin, wool, casein of milk, and other animal products are manufactured. (See protein.)

Ash. The portion of a feeding stuff which remains when it is burned, the incombustible part of feeds. The ash of feeding stuffs goes to make the skeleton of young animals, and in the case of milch cows a portion thereof goes into the milk as milk-ash.

Bacteria. Microscopic vegetable organisms usually in the form of a jointed rod-like filament, and found in putrefying organic infusions. They are widely diffused in nature, and multiply with marvelous rapidity. Certain species are active agents in fermentation, while others appear to be the cause of certain infectious diseases.

Balanced ration. A combination of feeding stuffs, containing the various nutrients in such proportions and amounts as will nourish the animals for twentyfour hours, with the least of nutrients.

By-products. A secondary product of an industry; cottonseed meal is a by-product of the cotton oil industry; skim milk and butter milk are by-products of butter making.

Carbohydrates. A group of nutrients rich in carbon and containing oxygen and hydrogen in the proportion in which they form water (Hydrogen two 
parts; oxygen one part, $\mathrm{H}^{2} \mathrm{O}$.). The most important carbohydrates found in feeding stuffs are starch, sugar, gums and crude fiber.

Carbon. A chemical element, which, with the elements of water, makes up the larger part of the dry matter of plants and animals.

Carbonic-acid. (Carbonic-acid-gas.) A poisonous gas arising from the combustion of coal or wood. It is formed in all kinds of fermentations and therefore occurs in deep silos. It is colorless, tasteless, odorless and heavier than air, therefore settles over the surface of ensilage, until disturbed by air currents or some other means.

Casein. The protein substance of milk which is coagulated by rennet or acids.

Concentrates. The more nutritious portion of the rations of farm animals embracing such feeding stuffs as wheat, bran, corn, oil-meal, etc., synonymous with grain feeds of concentrated feeds.

Fodder corn (corn fodder). Stalks of corn which are grown for forage, planted very thick, from which the ears or nubbins, if any, are not removed.

Corn stover. The dry corn stalks from which the ears have been removed.

Crude fiber. The frame work forming the walls of the cells of the plant (often referred to as being fibrous). It is composed of cellulose and lignin, the latter being the woody portion of plants and wholly indigestible.

Digestible matter. The portion of feeding stuffs which is digestible by animals, i. e., brought in solution or semi-solution by the digestive fluids, so that it may 
serve as nourishment for the animal and furnish material for the production of meat, milk, wool, eggs, etc.

Ensilage or Silage. A natural preservation of plants by exclusion of air. (See silage.)

Enzymes. An unorganized or chemical compound of vegetable or animal origin, that causes fermentation, as pepsin or rennet.

Ether extract. The portion of a feeding stuff dissolved by ether; mainly fat or oil in case of concentrated feeding stuffs; in coarse fodders, fat, mixed with a number of substances of uncertain feeding value, like wax, chlorophyll (the green coloring matter of plants).

Feed unit. A quantity of different feeding stuffs that has been found to produce similar results in feeding farm animals.

Feeding standard. A numerical expression of the amounts of various digestible substances in a combination of feeding stuffs best adapted to give good results as regards production of animal products, like beef, pork, mutton and milk, etc.

Fermentation. (Derived from fervere, to boil.) A chemical term being used to designate a peculiar class of metamorphoses which certain complex organic materials are liable to under pressure and exclusion of air.

Indian corn. Zea mays, the great American cereal and fodder producing plant.

Hydrogen. A chemical element, a gas. Combined with oxygen it forms water; combined with oxygen and carbon it forms carbohydrates; combined with oxygen, carbon and nitrogen (with small amounts of sulphur and phosphorus) it forms the complex organic nitrogenous substances known as protein or albuminoid substances, which see. 
Legumes. Plants bearing seeds in pods and indirectly capable of fixing the gaseous nitrogen of the air, so that it becomes of value to the farmer and will supply nitrogenous food substances for farm animals. Some of the legume plants are clover, sweet-clover, alfalfa, cow-peas, soy-beans, vetches, etc., which are of the highest importance agriculturally as soil renovators.

Moldy silage. A stage of decomposition, caused by air.

Nitrogen. A chemical element, making up fourfifths of the air. See hydrogen.

Nutrient. A food element or group of food elements capable of supplying nourishment for animals.

Organic matter. The portion of the dry matter which is destroyed on combustion.

Oxygen. A chemical element of which the air is composed of about one-fifth, and in the combination of two parts of hydrogen and one part of oxygen forms water. See hydrogen.

Preserving gas. (A term frequently applied to carbon-dioxide-gas.) A gas heavier than air and is commonly found in deep silos and wells. It settles to the lowest surface and remains there until disturbed by air currents or some other means. It is caused from the decomposition of vegetation, and is very dangerous.

Protein. A general name for complex organic compounds mainly made up from the following elements, carbon, hydrogen, oxygen and nitrogen. Protein crude, includes all organic nitrogen compounds, while true protein includes such nitrogenous substances in feeding stuffs as are capable of forming muscle and other tissues in the animal body.

Ration. The amount of feed that an animal consumes in one day. 
Roughage. The fibrous, coarse or rough part of plants, from which it takes its name and includes such feeding stuffs as stover, hay, straw, corn fodder, etc.

Rotten silage. A stage of decomposition of vegetation. It is worse than a loss. It is very dangerous and should not be fed to animals of any kind.

Silage. (See ensilage.)

Silo. An air-tight cylindrical structure used for the natural preservation of green vegetation, where it undergoes certain chemical changes.

Spoiled silage. The condition of silage as it appears in any one of the following forms: moldy, rotten, frozen, sour, frozen-thawed, or air-dried, all of which constitutes damaged silage, and if fed to stock the best results should not be expected. There are three ways to test silage: the chemical test, which is the most accurate, the aroma and the physical conditions of the silage, which is the most commonly used.

Succulent feed. Fresh, sweet ensilage. (See ensilage.)

Summer silage. It is feed, siloed in the fall and held over until the next summer when it is fed to stock to take the place of pastures. This is becoming popular in the middle west, especially with dairymen. 


\section{CHAPTER XIV.}

\section{THINGS TO BE REMEMBERED.}

A loss does not necessarily mean the death of an animal, but anything that will cause the animal a setback is a loss, with a double meaning.

Should the feeder of silage persist on feeding damaged silage to his animals, it matters not whether it is fed through the folly of an experiment or through sheer ignorance, the results are the same, and a long chain of complicated troubles will certainly follow.

Don't feed rotten silage.

Don't feed moldy silage.

Don't feed frozen silage.

Don't feed sour silage.

Don't feed silage that has been once frozen and then thawed, it is damaged.

Don't harvest the corn too green, wait until it is more nearly matured.

Don't feed stock too much silage on the start. Light feeding, then gradually increase the ration, will give the best results.

Don't feed silage that is too dry, it causes soreness of the mouth.

Don't cut silage more than one inch long, shorter if possible.

Don't leave the door of the silo open, air causes silage to spoil.

Don't leave the roof off (or open) on the silo, heat will escape. 
Don't store fodder in the silo too dry, add a little water.

Don't give animals ice water to drink, it chills them.

Don't allow any animal to stand and lay down in mud or manure.

Don't feed the milch cow silage before milking, but immediately afterwards.

Don't scold, kick and lose fellowship with the milch cow, she is a producer. 


\section{Three Mortgage Lifters}

The Silo

The Manure Spreader

The Cream Separator 





\section{LIBRARY OF CONGRESS}

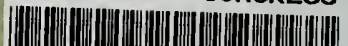

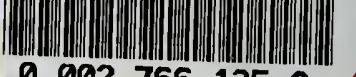

$0002766 \quad 135$ A 